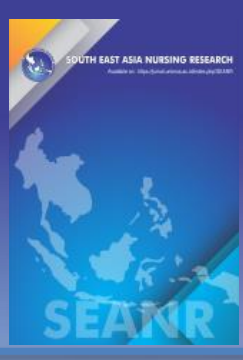

Case Study

\title{
Handover Nurse Monitoring and Evaluation In Meeting The SNARS Accreditation Standards 1.1
}

\author{
Kurnia Yuliastanti'1,2, Vivi Yosafianti Pohan², Tri Hartiti² \\ ${ }^{1}$ Nursing Department, Sultan Agung Islamic Hospital Semarang, Indonesia \\ 2 Master of Nursing Program, Universitas Muhammadiyah Semarang, Indonesia
}

\section{Article Info}

\section{Article History:}

Submit Dec 10th, 2020

Accepted Dec 30th, 2020

Published Dec 30th 2020

\section{Keywords:}

Monitoring and Evaluation;

Nurse Handover; Nursing

Management

\begin{abstract}
Sultan Agung Islamic Hospital Semarang as one of the providers of health, education and research services must be supported by a strong organization and good management. The nurse plays an important role regarding the clinical outcome of the client, especially during the handover the process which has an impact on patient safety and the quality of the hospital. The implementation of monitoring and evaluation of handover in this hospital has never been implemented because there are no working tools and regulations that regulate it as a reference for implementation. This study uses the interviews and observations with the approach carried out on 7 19 December 2020. Participants consisted of the Responsible Person / Head of the Room, the Responsible Nurse (PPJA) and the Implementing Nurse (PP) in the Baitul Izzah 2 room of the Sultan Agung Islamic Hospital Semarang. This study found 3 themes were found, namely the absence of monitoring and evaluation of handover nurses, lack of understanding of nurses regarding the implementation of handover monitoring and evaluation, the absence of regulations and work tools regarding the handover monitoring and evaluation. Work tools and regulations are very helpful in the implementation of monitoring and evaluation of handover in providing nursing care in the inpatient room. As well as fulfilling SNARS 1.1 Accreditation standards.
\end{abstract}

\section{INTRODUCTION}

Sultan Agung Islamic Hospital Semarang as one of the providers of health, education and research services, aims to improve health status and is always oriented towards the interests of the community. For that, the hospital needs to be supported by the existence of a strong organization and good management oriented towards the quality of service for the community.
Nursing management is a process of working through members of the nursing staff to provide nursing care professionally. It is a special task that must be carried out by nursing managers to plan, organize, direct and supervise existing resources, both human resources, tools and funds so that they can provide effective nursing services to patients, families and communities. ${ }^{1}$ Meanwhile, a nursing service is a form of professional service that is an integral part of health services based on

Corresponding author:

Kurnia Yuliastanti

kurniayuliastanti@gmail.com

South East Asia Nursing Research, Vol 2 No 4, December 2020

ISSN:2685-032X

DOI: https://doi.org/10.26714/seanr.2.4.2020.43-47 
nursing knowledge and tips for individuals, families, groups or communities, both healthy and sick. Nursing practice is a service provided by nurses in the form of nursing care. ${ }^{2}$

Nurses as an integral part of health services are required to have strong managerial abilities so that the services provided can increase patient satisfaction. Nurses' managerial abilities can be achieved in many ways. One of them is by increasing reliable managerial skills based on innovation and evidence-based. ${ }^{3}$ The nurse must know the concept correctly and have a positive attitude and be prepared to apply the evidence-based practice. In the inpatient installation, the nursing staff are in the forefront of the health service system with the first and longest contact with the patient, which is 24 hours per day and 7 days per week, therefore nurses hold a key position in building the image of the hospital. Nursing services in the hospital are the biggest activity producers so that they reflect the quality of hospital services. This quality can be seen from one of them through the implementation of Handover nurses when weighing receipts between shifts. ${ }^{4}$

National Hospital Accreditation Standards (SNARS) 1.1. The Patient Safety Goal (SKP.2.2) requires that the hospital establish and implement a communication process "Handover" and develop effective, timely, accurate, complete, clear and understandable communication methods for recipients. ${ }^{5}$ Weigh-acceptance is a technique used to convey and receive reports in connection with the client's condition, which is carried out between nurses and nurses and between nurses and clients in an accurate and more real way, it must be clear, concise and complete. Acceptance weighing is carried out starting from preparation, implementation at the nurse station and continued beside the patient's bed or bedside handover, as well as post-consideration. ${ }^{1}$
Patient handover is designed as a method to provide relevant information to the nursing team at each shift, as a practical guide providing information about the patient's current condition, treatment goals, treatment plans and determining priority services that are carried out in a timely, accurate, complete, and clear manner, so that it can be understood, and will reduce errors, and result in increased patient safety. ${ }^{6}$

Handover implementation in several hospitals in Indonesia is still not optimally implemented. This shows that the handover condition still requires a lot of improvement and recommendations to become a better process. Therefore, if the communication in handover is not effective, it can cause errors in the continuity of services and improper treatment and result in potential losses for patients. ${ }^{7}$

Baitul Izzah 2 room is an adult inpatient room led by a Person in Charge / Head of Room with 4 (four) Nurses in Charge of Care (PPJA). PPJA in implementing nursing care is assisted by 17 implementing nurses (Associate Nurse / PA). The room designated as a practice place for nursing management applications, is an adult care room for classes I and III with cases of Internal Medicine, Eyes, Nerves, ENT, Skin and genitals, and Teeth and Mouth. Has a capacity of 26 patient beds (TT). BOR for the last 3 (three) months averaged $73.5 \%$. The number of nurses is 21 (twenty-one) with D3 Nursing Education amounting to 17 and Nurse Education: amounting to 4.

Based on the results of the assessment, through interviews and observations made to the Head of the Baitul Izzah 2 Room at the Sultan Agung Islamic Hospital, Semarang revealed that in the application of the second patient safety goal, namely increasing effective communication, manifested in the implementation of nurse handover between shifts. Handover is carried out at the nurse station then proceed to the patient's bedside (bedside 
handover). For the handover the material, the nurse uses the patient's medical record data and uses a tool in the form of an SBARbased Handover Form (Situation, Background, Assessment, Recommendation). The handover is routinely carried out and runs smoothly, however so far there has never been any monitoring or evaluation related to the implementation of the handover. This study aims to determine the implementation of Handover Nurse Monitoring and Evaluation In Meeting The SNARS Accreditation Standards 1.1.

\section{METHODS}

The scientific way to obtain data with specific purposes and uses. $^{8}$ Activities carried out in obtaining data through observation and interviews, started with problem identification, then continued with problem analysis, determination of problem priorities, preparation of plans of action, implementation, and evaluation of structures, processes and results. The data is used in determining the problems identified using a fishbone diagram. The method used to determine the priority of several problems using the CAR method, which consists of:

$\mathrm{C}=$ Capability, namely the availability of resources (funds, facilities and equipment)

$\mathrm{A}=$ Accessibility, namely convenience, the existing problem is easy to solve or not. Convenience can be based on the availability of methods/methods/technology as well as implementation support such as regulations or implementation guidelines.

$\mathrm{R}=$ Readiness, namely the readiness of the executive staff and the readiness of targets, such as expertise or ability and motivation.

$\mathrm{L}=$ Leverage, namely how much influence the criteria have on one another in solving the problems discussed.
To get the priority value, that is by multiplying the value of each criterion. The higher the value of the product, the more priority the problem is to solve.

\section{RESULTS}

In determining the problem according to the CARL method, there are 2 (two) problems, namely:

1. Not yet implemented monitoring and evaluation of Handover by the Head of the Room (score 256)

2. Not yet implemented nursing supervision activities by the head of the room, the team leader in a structured manner (score 96)

Based on the highest score, the priority of the problem in the Baitul Izzah 2 room is "The Head of the Room has not carried out monitoring and evaluation of Handover".

Intervention implemented by conducting socialization/ refreshing about handover through zoom meeting. Followed by coordination and consultation with the Head of Nursing and the Head of the Room for making work tools in the form of monitoring forms, evaluation forms and making SPO Monitoring and SPO Evaluation handover.

On December 10, 2020, the form and SPO were socialized directly to the Head of the Room, PPJA and PP continued with implementation on December 11, 2020. Form and SPO were well received by all Baitul Izzah Room nurses 2. Implementation was carried out with continuous assistance

Interviews and observations to the Head of the Room and PPJA obtained data on the implementation of the monitoring form, evaluation form, SPO monitoring and SPO evaluation can be carried out smoothly. The form is filled in completely, the nurse also does not feel burdened in filling out the complete form. With this form, it makes it 
easier for nurses to handover. Nurses are more able to focus and be structured on what things will be handed over to the next shift. The information provided is more accurate, which can minimize errors in communication that can harm patients.

\section{DISCUSSION}

Based on the results of interviews and observations, the patient's overall handover from the preparation, implementation, and post-consideration stages constitutes a unified process that becomes one of the activities that support nursing services on an ongoing basis and with integrity through reporting and documentation. ${ }^{1}$ Following the purpose of the consideration and acceptance based on the SPO of the Sultan Agung Islamic Hospital Semarang which was issued on January 7, 2020, among others, is to improve communication skills between nurses so that there is a responsible collaborative relationship between members of the nursing team and can follow the complete development of clients and the implementation of nursing care towards clients on an ongoing basis.

Efforts to improve service quality following standards and following the latest hospital accreditation provisions Handover, in Baitul Izzah 2 room have been implemented following the existing SPO. Handover is carried out every shift change at the nurse station then continued to the patient's bedside (bedside handover). For the handover the material, the nurse uses the patient's medical record data and uses a tool in the form of an SBAR-based Handover Form (Situation, Background, Assessment, Recommendation). The method of implementing this weigh-and-receipt has been implemented since the issuance of the SPO as a reference for the implementation of the handover. There were no obstacles in its implementation. It was found that the handover had never been monitored and evaluated in its implementation. Whereas in the SNARS 1.1 Accreditation standard.5
The Head of the Room, PPJA and PP do not carry out monitoring and evaluation due to lack of understanding and understanding, that handover must always be monitored and evaluated to find out any obstacles in its implementation for quality assurance and patient safety. The impact if this happens continuously and there is no improvement or improvement, it will have a negative impact on the implementation of the consideration itself, for the staff or nurses who carry out these activities and for the institution which is the container and provider of the facilities, and especially for patients as clients who involved in this activity. Thus, this activity will ultimately have an impact on patient safety goals which ultimately lead to patient satisfaction with the service and quality of the hospital institution.

With the existence of forms, SPO monitoring and evaluation handover, monitoring and evaluation are always carried out in every handover implementation. In interviews and observations to the Head of the Room and PPJA, the monitoring form, evaluation form, monitoring SPO and SPO evaluation were carried out properly. The form is filled in completely and the nurse finds it easy to carry out the contents of the form. Nurses can be more focused and structured on what things will be handed over to the next shift. the information provided is more accurate, which can minimize errors in communication that can harm the patient

The positive impact felt by the nurses themselves is to motivate to improve communication skills between nurses, to establish a cooperative and responsible relationship between nurses and to be able to follow the patient's development comprehensively ${ }^{9}$. Nurses' job satisfaction in nursing practice is achieved when the nurse feels that she has contributed, is considered important, has received support from existing sources, and many nursing outcomes are achieved. ${ }^{10}$ 


\section{CONCLUSION}

Activities run well and can increase the knowledge and skills of nurses in the application of monitoring and evaluation of handover nurses. It was shown from the results of the mentoring evaluation that the implementation of monitoring and evaluation of handover nurses had been carried out well with $100 \%$ achievement which previously did not exist. This was supported by the joint commitment of all nurses in the Baitul Izzah 2 care room to always carry out monitoring and evaluation of handover.

\section{ACKNOWLEDGMENTS}

The author is thankful to Sultan Agung Islamic Hospital Semarang and the nurses who took part in this study.

\section{CONFLICTS OF INTEREST}

The author disclosures no potential conflicts of interest, financial or otherwise.

\section{REFERENCES}

1. Nursalam. Manajemen Keperawatan Aplikasi dalam Praktik Nursalam. (2011). Manajemen Keperawatan Aplikasi dalam Praktik Keperawatan Profesional Edisi 3. Salemba Medika.

https://doi.org/10.1001/archinte.165.22.2659
Keperawatan Profesional Edisi 3. Salemba Medika. 2011.

2. Budiono. Konsep Dasar Keperawatan. Kementrian Kesehatan Republik Indonesia; 2016.

3. Legita T. Pengetahuan, Sikap dan Kesiapan Perawat Klinisi Dalam Implementasi EvidenceBase Practice. NERS J Keperawatan. Published online 2012. doi:10.25077/njk.8.1.84-97.2012

4. Triwibowo C, Yuliawati S, Husna NA. Handover Sebagai upaya Peningkatan Keselamatan Pasien (Patient Safety) di Rumah Sakit. J Keperawatan Soedirman. Published online 2018. doi:10.20884/1.jks.2016.11.2.646

5. Komisi Akreditasi Rumah Sakit. Standar Nasional Akreditasi Rumah Sakit. KARS; 2017.

6. Faisal F, Syahrul S, Jafar N. Pendampingan Handover Pasien Dengan Metode Komunikasi Situation, Background, Assesment, Recommendation (SBAR) Pada Perawat Di RSUD Barru Kabupaten Barru Sulawesi Selatan. J Terap Abdimas. Published online 2019. doi:10.25273/jta.v4i1.3807

7. Kamil H, Keilmuan B, Dasar K, et al. Handover Dalam Pelayanan Keperawatan. Idea Nurs J. Published online 2011.

8. Sugiyono. Metodologi Penelitian. Univ Pendidik Indones. Published online 2003.

9. Aiken LH, Clarke SP, Sloane DM, et al. Nurses' reports on hospital care in five countries. Health Aff. Published 2001. doi:10.1377/hlthaff.20.3.43

10. Marquis BL, Huston CJ. Leadership Roles and Management Functions in Nursing: Theory and Application.; 2017. doi:10.1097/00006216200407000-00013 